\title{
Self-assessment in education management training through distance learning: A critical analysis
}

\author{
G. M. Steyn \\ School of Education \\ University of South Africa \\ Pretoria, South Africa \\ Steyngm1@unisa.ac.za
}

\author{
G. D. Kamper \\ School of Education \\ University of South Africa \\ Pretoria, South Africa \\ KAMPEGD@unisa.ac.za
}

\begin{abstract}
In pursuit of quality, the learning process should be continuously improved by changing, among other things, the learning material and the way learning is facilitated. A concern for academics, teaching experience in the B.Ed. module: Personnel Management, a module offered by means of distance education at the University of South Africa, is to ensure that learners progress beyond the mere completion of assignments to where they commit themselves to construing the learning material and to developing management and leaderships skills. A means of achieving this is to change the assessment system of assignments. During $2003 \mathrm{a}$ single, extensive assignment was set, which consisted of nine activities linked to the nine themes covered by the module. A detailed memorandum with a marking schedule for the assignment was issued to students at registration.

In this article the following issues are covered: the approach to learning in the module; features of self-assessment and students' perceptions of the learning content and assessment system. Quantitative methods of data gathering were employed to explore learners' responses to the assignment and assessment system in the B.Ed. module: Personnel Management.
\end{abstract}

\section{INTRODUCTION}

The complexity of educational management and the need for innovative solutions to educational management problems require a challenging approach to designing educational management training materials. In practice, educational leaders are faced with difficult issues and situations. These issues and situations are typified by unique events to which there are no uniform answers. As such, educational management training should, therefore, acknowledge not only the various settings 
from which learners come, but also learners' related experiences in practice, the status of their personal and professional development, their unique personal characteristics and the different post levels which they occupy.

This poses particular challenges for distance learning. The nature of distance learning demands effective communication. However, in distance learning the communication channels used can often result in a loss of information and rapport when compared with face-to-face tuition. Distance learners often experience a feeling of isolation and remoteness from fellow learners (Macdonald and Twining 2002, 603; Stacey and Rice 2002, 326). Moreover, they do not have the benefit of the immediacy of assessment carried out by the classroom educators, and therefore they may experience uncertainties about the direction and effect of their learning (White 1999, 38). For distance learners, this need can be addressed through sophisticated measures of self-assessment. In this regard, the work of Donald Schön (1983) on reflective practice for improvement of teaching (Pereira 1999, 339 ) is inspiring. Nevertheless, there is still a need to evaluate the extent to which learners engage in the learning material through self-assessment as intended by the learning design (cf. Stacey and Rice 2002, 323).

In this article, the authors report on an institutional research project that was aimed at learner evaluation of the effectiveness of self-assessment in the distance learning context, with a view to the continuous improvement of the learning design. More particularly, the following question is addressed: What are learners' views on the self-assessment system in the Personnel Management module?

The point of departure is a brief exposition of the education management module that serves as a unit of analysis. Then, provisions are given for the theoretical underpinnings of the approach to learning followed in the design of this module, with due attention to self-assessment. The gist of the article covers the empirical survey of learner views regarding the self-assessment aspects of the module. The crucial role played by self-assessment implies the need for probing its success. A case study of such a probe is presented.

\section{UNIT OF ANALYSIS}

The Personnel Management module of the B.Ed Hons. course in Educational Management at the University of South Africa (Unisa) is directed to professionals in education, who, aspire to educational management positions, as well as to currently employed educational managers. The course, therefore, serves as preservice management training for most learners (educators). It also serves as inservice training for a considerable number of learners who are school principals, deputy principals and heads of departments.

The module content has been divided into three themes that are covered in separate study guides:

- Guide 1: Interpersonal relationships (Sub-themes: Self-management; Effective communication; Conflict resolution and management) 
- Guide 2: Empowering people (Sub-themes: Working with teams; Staff motivation and job satisfaction; Managing stress)

- Guide 3: Resourcing and development; (Sub-themes: Staffing and staff induction; Professional development; Staff appraisal).

To facilitate and direct reflection and active learning in this module, nine extensive activities are set. These activities are directly linked to the nine topics dealt with in the module. A suggested timetable for completion of these activities throughout the year is provided to help learners plan their work.

The learning material is further expanded by way of a reader consisting of 43 articles covering all the topics in the three themes and a fourth study guide. The latter consists of a detailed memorandum of reflection activities on each topic and a marking schedule to assist learners in their own learning.

The approach to learning underpinning the module is discussed in the ensuing paragraph.

\section{THE APPROACH TO LEARNING IN THE MODULE}

The approach to learning underpinning the module in Personnel Management is reflected in the following introductory remark to learners (Tutorial Letter-101/ 2003):

Our role as educators will be to facilitate your acquisition of theoretical and practical knowledge. You may differ from some theoretical assumptions in view of your own unique circumstances - they are at best an interpretation of reality but do not claim to be reality itself. This means that you will be expected to obtain theoretical knowledge with insight and understanding, and to analyse, compare and evaluate your situation in the light of this theoretical knowledge.

Even the guidelines provided in various themes may differ from what you have already learnt from experience. Theoretical prescriptions cannot be passively accepted and mechanically applied. Your experience is a most valuable source of information - in fact it is your 'theories in practice'. We therefore require a critical approach here too.

According to developments in higher education where the traditional, dominant paradigm, termed the instruction paradigm is making way for the learning paradigm (Barr and Tagg 1995, 14), the module takes the latter as point of departure. The learning paradigm does not prescribe a single 'answer' to the question of how to organise learning environments and experiences (Barr and Tagg 1995, 20). According to this paradigm, learning environment and activities are learner- centred and learner-controlled. They may even be 'educatorless'. Educators may have designed the learning experiences, but they need not be present nor participate in every structured learning activity. They also accept the 
ultimate responsibility of the facilitation of learning in the support of learning (Haynes 2002, 21; Starness and Paris 2000, 393; Chrenka 2001, 694; Wisniewski 2003, 34; Anderson and Freiberg 1995, 79). This implies that learners, the coproducers of learning, assume responsibility for their own learning. The fact that two agents (educator and learner) take responsibility for the same outcome results in a synergy that produces powerful results.

The following sections provide a brief exposition of the components of the learning paradigm as used as basis for the development of the module and the role of self-assessment in them. They are reflective inquiry, critical thinking and constructivism.

\subsection{Reflective inquiry}

In their patterns of action, much of the educators' practical knowledge is tacit or implicit (Drevdahl, Stackman, Purdy and Louie 2002, 415; Price 2000, 100), and therefore used almost unconsciously and intuitively (i.e., non-self-regulatory). According to Drevdahl et al. $(2002,415)$, reflection is a mechanism to make this knowing and meaning more explicit. Reflection is regarded as a fundamental feature of self-regulation and a necessary condition for expansion of the metacognitive knowledge body (Masui and De Corte 1999, 521; Birenbaum and Amdur 1999, 203; Day 1999, 222). By means of reflection educators develop both responsibility and accountability for their decisions in practice, which assumes a continuous involvement in reflection during the course of their career (Day 1999, 222). This implies the notion of reflective inquiry which is an approach that uses a 'deliberative process' critical to demonstrating the hidden knowledge of both teaching and Personnel Management (Schmieding in Drevdahl et al. 2002, 415).

The aim of reflective inquiry is to improve the practice of the overall discipline through knowledge creation (Drevdahl et al. 2002, 415; Yost, Sentner and Forlenza-Bailey 2000, 40; Pereira 1999, 342). It involves the learner in a critique of his or her practice, the values implicit in the practice, the climate in which practice occurs and the implications of these for improving practice (Day 1999, 222). When practitioners engage in reflective inquiry they hope to improve practice by identifying and integrating knowledge, thought and action in a cyclical process of reflection and inspection (Drevdahl et al. 2002, 415; Yost et al. 2000, 41). Therefore, reflective inquirey contributes to developing self-awareness and new knowledge, which then leads to change (Brunyee 2000, 179; Pereira 1999, 349).

The facilitation of reflective inquiry consists of the following phases: reflective learning which is a process of encompassing enlightenment (helping practitioners to understand who they are), empowerment (taking the necessary steps to change) and emancipation (freeing practitioners from their previous ways of doing things to be reconstituted as new practitioners) (Johns in Drevdahl et al. 2002, 416; Anderson and Freiberg 1995, 79). 


\subsection{Critical thinking}

The development of critical thinking skills has been identified as one of the 12 critical outcomes of the South African Qualifications Authority (Department of Education 1998, 8). Maximising human potential and achieving cognitive change are considered to be the results of critical thinking (Yost et al. 2000, 41; Patterson, Crooks and Lukyk-Child 2002, 30). Although the end result of critical thinking is cognitive change in the individual, the ultimate aim of the engagement is to bring about significant change in schools (Yost et al. 2000, 46). Opportunities to practise and transfer learned activities to new contexts should, therefore, be created (Masui and De Corte 1999, 524; Pienaar 2001, 127; Wisniewski 2003, 34).

Critical thinking involves purposeful, goal-directed thinking that is directed towards making judgements based on evidence and application of principles of science (Patterson et al. 2002, 30; Pienaar 2001, 127). It involves thinking and problem solving that will enable practitioners to find solutions to complex managerial problems in schools (Yost et al. 2000, 39, 46; Lehtinen 2002, 110; Pienaar 2001, 130). In problem solving the learners try to make sense of challenging situations, identify areas of practice requiring examination, define goals for improvement and exercise actions to attain them (Yost et al. 2000, 41; Lehtinen 2002, 110). Reconstruction of knowledge is regarded as the end result of problem solving (Yost et al. 2000, 41; Lehtinen 2002, 110; Wessels 2001, 45; Price 2000, 99; Hollingworth and McLouglin 2001, 51).

\subsection{Constructivism}

According to the constructivist learning theory, learning is not the result of teaching, but rather the result of what learners do with the new information presented to them (Sewell 2002, 24; Sahin 2003, 68; Howland and Moore 2002, 183; Pereira 1999, 345). In this framework, learning is an active process that is learner-centred (Chrenka 2001, 694; Macdonald and Twining 2002, 606; Birenbaum and Amdur 1999, 202; Weasmer and Woods 2000, 16). Learners are expected to construct their own unique understanding based on prior knowledge and experience (McVarish and Solloway 2002, 254; Howland and Moore 2002, 183; Macdonald and Twining 2002, 605; Masui and De Corte 1999, 523; Wisniewski 2003, 34; Pereira 1999, 345). Therefore constructivism emphasises the importance of examining previous experiences and knowledge (Yost et al. 2000, 42; Sahin 2003, 68).

It is important to realise that constructive educators do not abdicate their responsibility to 'teach' (Chrenka 2001, 694; Pereira 1999, 345). Learners, with the help of educators, actively construct and transform the information and construct their own meaning (Pereira 1999, 345; Biswala 2001, 63; Weasmer and Woods 2000, 16). As such, educators have to build on learners' existing knowledge and experiences, since their understanding and interpretation of the learning material depend on that (Wisniewski 2003, 34). 
The notions of reflective inquiry, critical thinking and constructivism all point to the crucial role of self-assessment in the learning process.

\section{FEATURES OF SELF-ASSESSMENT}

Traditional testing methods are out of keeping with goals such as lifelong learning, reflective practice, critical thinking, constructivism and problem solving (Dochy, Segers and Sluijsmans 1999, 332; cf. Lehtinen 2002, 109). Assessment needs to support student-centred learning and the development of particular skills (Macdonald and Twining 2002, 606). Since the focus in higher education is gradually changing from teaching to learning and from educator management to self-directed learners, interest has arisen in the benefits of alternative methods of assessment, such as learners' self-assessment (Hanrahan and Isaacs 2001, 53; Anderson and Freiberg 1995, 79).

Learners enrolling for higher education programmes aim to gain employment on a professional level (Adams and King 1995, 327). In the case of B.Ed. learners in Educational Management, they aim to be appointed as educational managers, move to higher positions or become more effective educational managers if they already occupy management positions. Employment at a professional level usually requires expertise and the ability to work on personal initiative. A crucial part of this ability is to self-appraise. In other words, to have a continual knowledge of one's own capabilities and to be able to update shortcomings appropriately (Adams and King 1995, 327). Purdy (1997, 137) supports the view of Adam and King by stating that self-assessment is central to any process of individual personal development in all professions.

Self-assessment is defined as the process in which the learner determines the extent of his or her knowledge and skills in a field of study by assessing his or her responses to activities in the learning material and assignments (cf. Van Kraayenoord and Paris 1997, 525). This includes the reflection on certain appropriate activities for the sake of improved performance in future situations (cf. Stallings and Tascione 1996, 548). In this kind of assessment the educator is replaced as sole judge while, at the same time, requiring ownership by the learner of the learning and assessment process (McVarish and Solloway 2002, 254; Anderson and Freiberg 1995, 79). Thus, self-assessment entails the active involvement of learners in making judgements of their own learning (Dochy et al. 1999, 334; Biswala 2001, 63). Self-assessment empowers learners by taking away their dependency on educators to provide them with feedback on the quality of learning (Anderson and Freiberg 1995, 88). Learners' self-assessment of specific accomplishments in learning activities, as well as longitudinal assessment of progress, is fundamental to the development of independent learning and positive motivation. Knowledge is, however, given and received by all role players involved in the learning process and, therefore, the power is more equally shared across roles (McVarish and Solloway 2002, 254; Weasmer and Woods 2000, 20). 
According to the study by Peckham and Sutherland (2000, 78), self-assessment can be a highly reliable means of assessment. Self-assessment as mainly a formative kind of assessment, that is, one that provides learners with feedback on their learning, has been successfully used to promote learning (Peckham and Sutherland 2000, 76; Anderson and Freiberg 1995, 79). Since, in the course of selfassessment, learners have to reflect profoundly on their own learning processes and outcomes (Dochy, et al. 1999, 334; Anderson and Freiberg 1995, 79), it trains learners to become independent and self-monitoring (Peckham and Sutherland 2000, 76). Patterson et al. (2002, 28), however, warn that learners' self-assessment is one skill that causes them the most discomfort. This can be overcome by providing clearer and more detailed memoranda and assessment criteria that will enhance self-efficacy (Hanrahan and Isaacs 2001, 67). Moreover, the accuracy of self-assessment can increase over time once learners are provided with more opportunities for such a system of assessment (Dochy, et al. 1999, 337).

In summary, self-assessment is a crucial aspect of teaching and learning in higher education, informing reflective practice, self-study and continuing professional development, and constituting a fundamental aspect of learnercentred approaches to the support of learning (Bleakley 2000, 405; Peckham and Sutherland 2000, 75). These features of learning are essential if learners are to become independent learners. The extent to which this outcome is reached must be determined. Thus, a learner survey (as mentioned earlier) forms an integral part of the Personnel Management module.

\section{$5 \quad$ RESEARCH DESIGN AND FINDINGS}

Annually, learners enrolled for the Personnel Management module have to complete a questionnaire consisting of 82 items. The purpose with the questionnaire is twofold, namely (1) to serve as a self-assessment instrument for learners to reflect on their interaction with the learning material through various activities, and (2) to capture learners' opinions on the self-assessment system used. The questionnaire has a section on biographical information, nine subsections on the different topics and a section on the assignment system of the module.

The 2003 enrolment for the Personnel Management module comprised 343 learners, from whom 243 questionnaires were received. This constitutes a response rate of 70.8 per cent.

The findings are presented according to the topical sequence in the questionnaire, namely biographical information; learner evaluation of their interaction with content; and learner rating of the self-assessment practice used. 


\subsection{Biographical information}

It appears that 78 per cent of learners were in the age group of 35 years and older. This is not unexpected for enrolment in a management module. Many educators with a number of years of teaching experience wish to be promoted and know that formal qualifications would be to their advantage. The majority of learners were on the educator level $(60,91 \%)$, compared to other management levels of head of department $(20,16 \%)$, deputy head (4.94\%) and principal (11.93\%). It is clear that the Personnel Management module has to cater for educators who are aspiring to management positions, as well as for those already in such positions, but desire formal education management training in order to be better equipped.

The vast majority of learners (78\%) were female. The high percentage of female learners reflects the gender composition in the teaching profession. However, ithas to be remembered that the inequity of the past has been purposively redressed in recent years, and female educators are in a better position to be promoted to management positions. This development is undoubtedly a factor contributing to the relatively high enrolment of female learners.

\subsection{Learner evaluation of activities}

To facilitate and direct reflection and active learning in this module, nine extensive activities have been set. These activities are directly linked to the nine themes dealt with in the module, and provide for interviews, role play, observation, case studies, text analyses, scenarios and reflections on personal experience. Some activities require learners to request colleagues (or other teaching professionals) to evaluate their own effectiveness in the activities. The rationale for including colleagues (or other professionals) is to give a learner the opportunity to reflect on, and justify his or her actions, in view of peer evaluation.

Upon registration learners receive the nine activities in a single assignment, as well as a complete memorandum as self-assessment guide. The memorandum includes a detailed marking schedule for each activity. Since the activities are designed to stimulate and demonstrate learners' personal involvement and experience in various practical situations, the copying of activity answers is unlikely. A timetable for completion of these activities throughout the year is suggested to help learners plan their work.

Table 1 indicates the rating of learning resulting from the participation in, and self-assessment of, the activities.

A comparison of the 'Yes' with the 'Definitely yes' responses reveals a considerable degree of reservation in opting for the latter. The reasons for this have to be determined, and will undoubtedly indicate ways to improve the module. The responses nevertheless reveal learners' positive view of the activities (interviews and role play) and the appropriateness of the difficulty level of the activities. Since the activities constitute the backbone of the learning approach followed in the module (as discussed earlier), these findings were heartening. 
Table 1: Rating of learning resulting from activities

\begin{tabular}{|l|c|c|}
\hline Q62 I learnt a lot about my organisation (school or & Frequency & $\%$ \\
otherwise) by conducting the different interviews. & & \\
\hline Definitely no & 1 & 0.42 \\
No & 5 & 2.09 \\
Yes & 106 & 44.35 \\
Definitely yes & 127 & 53.14 \\
Total & 239 & 100 \\
\hline Q63 By conducting interviews I have developed my & Frequency & $\%$ \\
management skills. & & \\
\hline Definitely no & 1 & 0.42 \\
No & 7 & 2.93 \\
Yes & 100 & 41.84 \\
Definitely yes & 131 & 54.81 \\
Total & 239 & 100 \\
\hline Q64 I learnt a lot by doing the role-play exercises. & Frequency & $\%$ \\
\hline Definitely no & 1 & 0.42 \\
No & 10 & 4.18 \\
Yes & 125 & 52.30 \\
Definitely yes & 103 & 43.10 \\
Total & 239 & 100 \\
\hline Q65 The participants in the role-play exercises helped & Frequency & $\%$ \\
me a lot. & & \\
\hline Definitely no & 1 & 0.42 \\
No & 11 & 4.58 \\
Yes & 128 & 53.33 \\
Definitely yes & 100 & 41.67 \\
Total & 240 & 100 \\
\hline Q66 The level of difficulty of the activities is appropriate & Frequency & $\%$ \\
for B Ed (Hons) students. & 108 & \\
\hline Definitely no & 116 & 48.33 \\
No & 240 & 100 \\
Yes & & \\
Definitely yes & & \\
Total & & \\
\hline & & \\
\hline
\end{tabular}

\subsection{Learner views on the self-assessment assignment}

The learners' self-assessment of their activities, together with the questionnaire, is submitted as one assignment towards the end of the year. Table 2 indicates the learner rating of various aspects of the assignment system. 
Table 2: Rating of the self-assessment assignment system

\begin{tabular}{|c|c|c|}
\hline $\begin{array}{l}\text { Q67 I prefer the assignment system where I submit only } \\
\text { one extensive assignment consisting of various activities. }\end{array}$ & Frequency & $\%$ \\
\hline $\begin{array}{l}\text { Definitely no } \\
\text { No } \\
\text { Yes } \\
\text { Definitely yes } \\
\text { Total }\end{array}$ & $\begin{array}{r}25 \\
53 \\
79 \\
83 \\
240\end{array}$ & $\begin{array}{l}10.42 \\
22.08 \\
32.92 \\
34.58 \\
100\end{array}$ \\
\hline $\begin{array}{l}\text { Q68 I like this assignment system of this module where I } \\
\text { control my own work schedule through the year. }\end{array}$ & Frequency & $\%$ \\
\hline $\begin{array}{l}\text { Definitely no } \\
\text { No } \\
\text { Yes } \\
\text { Definitely yes } \\
\text { Total }\end{array}$ & $\begin{array}{r}16 \\
45 \\
94 \\
85 \\
240\end{array}$ & $\begin{array}{l}6.67 \\
18.75 \\
39.17 \\
35.42 \\
100\end{array}$ \\
\hline $\begin{array}{l}\text { Q69 The availability of the answers to the activities } \\
\text { helped me a lot to develop my own understanding of the } \\
\text { learning content. }\end{array}$ & Frequency & $\%$ \\
\hline $\begin{array}{l}\text { Definitely no } \\
\text { No } \\
\text { Yes } \\
\text { Definitely yes } \\
\text { Total }\end{array}$ & $\begin{array}{r}1 \\
12 \\
83 \\
143 \\
239\end{array}$ & $\begin{array}{r}0.43 \\
5.02 \\
34.73 \\
59.83 \\
100\end{array}$ \\
\hline $\begin{array}{l}\text { Q70 A lecturer can expect a student on the B Ed (Hons) } \\
\text { level to be responsible enough to complete each activity } \\
\text { before consulting the memorandum. }\end{array}$ & Frequency & $\%$ \\
\hline $\begin{array}{l}\text { Definitely no } \\
\text { No } \\
\text { Yes } \\
\text { Definitely yes } \\
\text { Total }\end{array}$ & $\begin{array}{r}3 \\
15 \\
101 \\
119 \\
238\end{array}$ & $\begin{array}{l}1.26 \\
6.30 \\
42.44 \\
50.00 \\
100\end{array}$ \\
\hline $\begin{array}{l}\text { Q71 Incorporating a complete memorandum in the } \\
\text { assignment system provides a valuable learning experi- } \\
\text { ence. }\end{array}$ & Frequency & $\%$ \\
\hline $\begin{array}{l}\text { Definitely no } \\
\text { No } \\
\text { Yes } \\
\text { Definitely yes } \\
\text { Total }\end{array}$ & $\begin{array}{r}3 \\
16 \\
102 \\
118 \\
239\end{array}$ & $\begin{array}{r}1.26 \\
6.69 \\
42.68 \\
49.37 \\
100\end{array}$ \\
\hline
\end{tabular}




\begin{tabular}{|c|c|c|}
\hline $\begin{array}{l}\text { Q72 Compared to other assignment systems, I prefer the } \\
\text { immediate available answers to my activities rather than } \\
\text { to wait for feedback from the lecturers. }\end{array}$ & Frequency & $\%$ \\
\hline $\begin{array}{l}\text { Definitely no } \\
\text { No } \\
\text { Yes } \\
\text { Definitely yes } \\
\text { Tota }\end{array}$ & $\begin{array}{r}4 \\
38 \\
89 \\
108 \\
239\end{array}$ & $\begin{array}{l}1.67 \\
15.9 \\
37.2 \\
45.19 \\
100\end{array}$ \\
\hline $\begin{array}{l}\text { Q73 The fact that only credits for examination entrance } \\
\text { were awarded for the assignment as a whole, does not } \\
\text { affect the learning opportunity it creates. }\end{array}$ & Frequency & $\%$ \\
\hline $\begin{array}{l}\text { Definitely no } \\
\text { No } \\
\text { Yes } \\
\text { Definitely yes } \\
\text { Total }\end{array}$ & $\begin{array}{r}10 \\
20 \\
122 \\
84 \\
236\end{array}$ & $\begin{array}{l}4.24 \\
8.47 \\
51.69 \\
35.59 \\
100\end{array}$ \\
\hline $\begin{array}{l}\text { Q74 As an adult learner, I found that the assignment } \\
\text { system helped me to take responsibility for my own } \\
\text { learning. }\end{array}$ & Frequency & $\%$ \\
\hline $\begin{array}{l}\text { Definitely no } \\
\text { No } \\
\text { Yes } \\
\text { Definitely yes } \\
\text { Total }\end{array}$ & $\begin{array}{r}2 \\
1 \\
84 \\
152 \\
239\end{array}$ & $\begin{array}{l}0.84 \\
0.42 \\
35.15 \\
63.60 \\
100\end{array}$ \\
\hline $\begin{array}{l}\text { Q75 Marking my own assignment added to my learning } \\
\text { experience. }\end{array}$ & Frequency & $\%$ \\
\hline $\begin{array}{l}\text { Definitely no } \\
\text { No } \\
\text { Yes } \\
\text { Definitely yes } \\
\text { Total }\end{array}$ & $\begin{array}{r}4 \\
15 \\
100 \\
120 \\
239\end{array}$ & $\begin{array}{l}1.67 \\
6.26 \\
41.84 \\
50.21 \\
100\end{array}$ \\
\hline $\begin{array}{l}\text { Q76 It has been a relatively new experience for me to } \\
\text { mark an assignment of this kind. }\end{array}$ & Frequency & $\%$ \\
\hline $\begin{array}{l}\text { Definitely no } \\
\text { No } \\
\text { Yes } \\
\text { Definitely yes } \\
\text { Total }\end{array}$ & $\begin{array}{r}6 \\
16 \\
96 \\
122 \\
240\end{array}$ & $\begin{array}{r}2.09 \\
6.69 \\
40.17 \\
51.05 \\
100\end{array}$ \\
\hline
\end{tabular}




\begin{tabular}{|c|c|c|}
\hline $\begin{array}{l}\text { Q77 The extensive memorandum of the activities added } \\
\text { more to my learning than the usual feedback from lecturers } \\
\text { in other assignments. }\end{array}$ & Frequency & $\%$ \\
\hline $\begin{array}{l}\text { Definitely no } \\
\text { No } \\
\text { Yes } \\
\text { Definitely yes } \\
\text { Total }\end{array}$ & $\begin{array}{r}2 \\
26 \\
87 \\
124 \\
239\end{array}$ & $\begin{array}{l}0.84 \\
10.88 \\
36.40 \\
51.88 \\
100\end{array}$ \\
\hline Q78 I enjoyed marking my own assignment. & Frequency & $\%$ \\
\hline $\begin{array}{l}\text { Definitely no } \\
\text { No } \\
\text { Yes } \\
\text { Definitely yes } \\
\text { Total }\end{array}$ & $\begin{array}{r}15 \\
49 \\
96 \\
79 \\
239\end{array}$ & $\begin{array}{r}6.28 \\
20.50 \\
40.17 \\
33.05 \\
100\end{array}$ \\
\hline $\begin{array}{l}\text { Q79 The lecturers succeeded in facilitating my learning } \\
\text { in the assignment. }\end{array}$ & Frequency & $\%$ \\
\hline $\begin{array}{l}\text { Definitely no } \\
\text { No } \\
\text { Yes } \\
\text { Definitely yes } \\
\text { Total }\end{array}$ & $\begin{array}{r}0 \\
6 \\
118 \\
115 \\
239\end{array}$ & $\begin{array}{c}0 \\
2.51 \\
49.37 \\
48.12 \\
100\end{array}$ \\
\hline $\begin{array}{l}\text { Q80 I learnt little by comparing my own assignment with } \\
\text { the memorandum provided. }\end{array}$ & Frequency & $\%$ \\
\hline $\begin{array}{l}\text { Definitely no } \\
\text { No } \\
\text { Yes } \\
\text { Definitely yes } \\
\text { Total }\end{array}$ & $\begin{array}{r}56 \\
90 \\
\\
55 \\
36 \\
237\end{array}$ & $\begin{array}{l}23.21 \\
37.97 \\
\\
23.21 \\
15.19 \\
100\end{array}$ \\
\hline $\begin{array}{l}\text { Q81 Obtaining marks from a lecturer for an assignment } \\
\text { is more important than learning by completing the } \\
\text { assignment. }\end{array}$ & Frequency & $\%$ \\
\hline $\begin{array}{l}\text { Definitely no } \\
\text { No } \\
\text { Yes } \\
\text { Definitely yes } \\
\text { Total }\end{array}$ & $\begin{array}{r}48 \\
72 \\
66 \\
49 \\
235\end{array}$ & $\begin{array}{l}20.43 \\
30.64 \\
28.09 \\
20.85 \\
100\end{array}$ \\
\hline $\begin{array}{l}\text { Q82 I feel better equipped as an educational manager } \\
\text { after completing the extensive assignment. }\end{array}$ & Frequency & $\%$ \\
\hline $\begin{array}{l}\text { No } \\
\text { Yes } \\
\text { Definitely yes } \\
\text { Total }\end{array}$ & $\begin{array}{r}3 \\
70 \\
165 \\
238\end{array}$ & $\begin{array}{l}1.26 \\
29.41 \\
69.33 \\
100\end{array}$ \\
\hline
\end{tabular}


As in Table 1, the support for the 'Yes' vis-à-vis the 'Definitely yes' options is noticeable, suggesting areas for improvement where the former exceeds the latter. The items that attracted the strongest (Definitely yes) responses were: I feel better equipped as an educational manager after completing the extensive assignment (Q82 - 69.33\%); As an adult learner, I found that the assignment system helped me to take responsibility for my own learning (Q74-63.60\%); The availability of the answers to the activities helped me a lot in developing my own understanding of the learning content (Q69 - 59.83\%); The extensive memorandum of the activities added more to my learning than the usual feedback from lecturers in other assignments (Q77 - 51.88\%); Compared to other assignment systems, I prefer the immediate available answers to my activities rather than to wait for feedback from the lecturers (Q72-45.19\%). This measure of support is a decisive indicator that the choice of a self-assessment approach to the module was indeed meaningful.

Simply combining the 'Yes' and 'Definitely yes' responses reveals the following tendencies. The majority of learners $(67,5 \%)$ prefer the one extensive assignment set in the module, and 76.59 per cent of the learners preferred to plan their own work schedule, indicating the acceptance of the responsibility and ownership for their own learning (Haynes 2002, 21; Chrenka 2001, 694; Wisniewski 2003, 34). The vast majority of learners are full-time employees who prefer to complete the activities according to their work schedule.

The preference for the immediate availability of the memorandum is evident (94.56 per cent). It is therefore not surprising that the immediate availability of answers was regarded as beneficial to learners' learning experience (92.05 per cent). It implies that the memorandum could have assisted learners to become participants in a critique of their 'answers' by developing self-awareness and determining their level of knowledge (Pereira 1999, 349; Brunyee 2000, 179). Learners also accepted the responsibility to complete their activity before consulting the memorandum, which again confirms their taking the responsibility and accountability for their own learning (92.44\%).

The responses to item 75 explicitly indicate how learners viewed the way in which the assignment system helped them to take the responsibility for their own learning (98.75\%), which again supports the notion of responsibility and accountability outlined in the approach to the module. The vast majority of learners $(92.05 \%)$ indicated that assessing their own assignment had added to their learning experience, although self-assessment was a new experience to 91.22 per cent of the learners. It is noteworthy that 73.22 per cent of learners also enjoyed assessing their own work. Moreover, 88.28 per cent of the learners believed that they learned more from their own assessment than from the assessment of lecturers. This links up with the idea of reflective learning in which learners become critical thinkers by being empowered and emancipated as practitioners (Anderson and Freiberg 1995, 79; Johns in Drevdahl et al. 2002, 127). They succeeded in making judgements based on evidence (from their practice) and principles as outlined in the learning content. 
In the interests of identifying avenues for further improvement, a closer look at assessment issues that attracted the relatively higher number of responses contrary to self-assessment is worthwhile. These were the following:

Q81: Obtaining marks from a lecturer for an assignment is more important than learning from completing the assignment (Agreement: 49\%);

Q80: I learnt little by comparing my own assignment with the memorandum provided (Agreement: 38\%);

Q67: I prefer the assignment system where I submit only one extensive assignment consisting of various activities (Disagreement: 33\%);

Q78: I enjoyed marking my own assignment (Disagreement: 27\%);

Q68: I like the assignment system of this module where I control my own work schedule through the year (Disagreement: $25 \%$ ); and

Q79: The lecturers succeeded in facilitating my learning in the assignment. (Note the hesitance in opting for the 'Definitely yes' option.)

These percentages indicate that the preference for a mark-driven, externally controlled study situation is still disconcertingly strong among postgraduate students. Even more course design effort (through appropriate activities) is necessary to change this preference to a mindset of independent, reflective and critical interaction with learning materials.

On the whole, however, it is significant that almost all of the respondents (98.74\%) felt that they were better equipped as educational managers after completion of the extensive self-assessment assignment (Q82). This also supports the view that self-assessment is central to any process of individual personal development in a profession. Learners have become aware of their professional strengths and weaknesses and are now better equipped as professionals (Van Kraayenoord and Paris 1997, 534). It may also imply that learners have developed a sense of self-efficacy and optimism in their professional life.

\section{DISCUSSION}

It is clear that the contextualised nature of the study guides was appropriate, as is evident from the fact that so many learners experienced the learning process as relevant for adding value to work life. The empowerment of learners was further enhanced by the learning design that was particularly aimed at transferring the control of the learning process to the learners. Although the majority of learners expressed positive opinions, certain aspects require further attention. These mainly concern an increased realisation among learners of self-appraisal-assessment benefits in the institutional realm. There is also the need for strengthening learner dispositions of independency and critical self-reflection even further.

This study conclusively showed that the major benefit of self-assessment is its positive effect on learners' learning. Yet, the details of these effects are not always known. Hanrahan and Isaacs $(2001,67)$ pose the following pertinent questions: 
Does the self-assessment experience influence learners' general expectations of assessment? Do learners apply self-assessment in other areas of their life as a result of their positive experience of it? Do they expect or request that self-assessment be used in other modules too? These issues deserve further research.

This study verifies the following guidelines as given by Dochy et al. (1999, 346):

- It is important to provide training in self-assessment in order to accomplish optimal impact on the learning process.

- Self-assessment takes time, and support for learners in self-assessment is often required.

- Self-assessment can be relatively easily used for formative purposes and learners should learn to see this as a tool for learning.

- The entrenched practice of academics to do the teaching and marking is often hard to change and a shift to the reflective learning approach could require a staff development programme.

\section{CONCLUDING REMARK}

Much like the previous studies, the current study supports that learner selfassessment leads to increased personal skills such as critical reflection and critical thinking, increased interpersonal skills such as communication and stress management, and increased professional development and benefits for the institution. However, one would like to know whether these benefits are sustained or even enhanced over time. Follow-up surveys are essential: learner voices may lead one into new directions in research, and possibly to refinements of teaching and learning. It is especially important to establish longitudinally how learner attitudes about assessment and learning engagements evolve.

\section{REFERENCES}

Adams, C. and K. King. 1995. Towards a framework for student self-assessment. Innovations in Education and Training International November, 32 (4):336-343.

Allen, D. D. and R. F. Flippo. 2002. Alternative assessment in the preparation of literacy educators: Responses from students. Reading Psychology, January-March, 23 (1):15-26.

Anderson, J. B. and H. J. Freiberg.1995. Using self-assessment as a reflective tool to enhance student teaching experience. Teacher Education Quarterly Winter, 22 (1):77-91.

Arts, J. A. R., W. H. Gijselaers and M. S. R. Segers. 2002. Cognitive effects of an authentic computer-supported, problem-based learning environment. Instructional Science November, 30 (6):465-495.

Barr, R. B. and J. Tagg. 1995. From teaching to learning - a new paradigm for undergraduate education. Change November/December:13-25.

Bassi, L. J. 1997. Harnessing the power of intellectual capital. Training \& Development December, 51 (12):25-30.

Birenbaum, M. and L. Amdur. 1999. Reflective active learning in a graduate course on assessment. Higher Education Research \& Development 18 (2):201-218. 
Biswala, P. 2001. The systems approach as a catalyst for creating an effective learning environment for adults in part-time and distance learning. Convergence XXX1V (1):53-66.

Bleakley, A. 2000. Adrift without a lifeboat: Reflective self-assessment in a post-modern age. Teaching Higher Education 5 (4):405-418.

Brunyee, L. R. 2000. Selecting and adapting an industrial quality assurance model to promote self-evaluation and continuous improvement in a higher educational institution. South African Journal for Higher Education 14 (2):177-182.

Chrenka, L. 2001. Misconstructing constructivism. Phi Delta Kappa May, 82 (9):694-695.

Day, C. 1999. Professional development and reflective practice: Purposes, processes and partnerships. Pedagogy, Culture and Society 7 (2):221-233.

Department of Education. 1998. Regulations under the South African Qualifications Authority Act, 1995. Government Gazette. Pretoria: Government Printer.

Dochy, F., M. Segers and D. Sluijsmans. 1999. The use of self-, peer and co-assessment in higher education: A review. Studies in Higher Education October, 24 (3):331-350.

Drevdahl, D. J., R. W. Stackman, J. M. Purdy and B. Y. Louie. 2002. Merging reflective inquiry and self-study as a framework for enhancing the scholarship of teaching. Journal of Nursing Education September, 41 (9):413-419.

Griffin, C. and K. L. Kilgore. 1995. Framing the problems of practice: The effect of selfassessment in a study of special education students' internships. Teacher Education and Special Education Winter, 18 (1):56-71.

Hanharan, S. J. and G. Isaacs. 2001. Assessing self- and peer-assessment: The students' views. Higher Education Research \& Development May, 20 (1):53-70

Haynes, F. 2002. Is the learning paradigm a fad? The learning paradigm is an indicator of a maturing community college concept. Visions: The Journal of Applied Research for the Florida Association of Community Colleges Spring, 3 (1):20-24.

Hobson, E. H. 1996. Encouraging self-assessment: Writing the active learning. New Directions for Teaching and Learning Fall, no 67:45-58.

Hollingworth, R. W. and C. McLouglin. 2001. Developing science students' metacognitive problem-solving skills online. Australian Journal of Educational Technology 17 (1):50-63.

Howland, J. L. and J. L. Moore. 2002. Student perceptions as distance learners in internetbased courses. Distance Education October, 23 (2):183-195.

Kinnear, L. and M. Sutherland. 2000. Determinants of organisational commitment amongst knowledge workers. South African Journal of Business Management September, 31 (3):106112.

Lategan, L. O. K. 2002. 'The customer is king': A critical analysis of a customer-driven approach in higher education. Tydskrif vir Chistelike Wetenskap 38 (3/4):163-172.

Leder, G. C. 1993. Constructivism: Theory for practice? The case of mathematics. Higher Education Research and Development 12 (1):5-20.

Lehtinen, E. 2002. Developing models for distributed problem-based learning: Theoretical and methodological reflection. Distance Education May, 23 (1):109-117.

Masui, C. and E. de Corte. 1999. Enhancing learning and problem-solving skills: Orienting and self-judging, two powerful and trainable tools. Learning and Instruction December, 9 (6):517-542.

Macdonald, J. and P. Twining. 2002. Assessing activity-based learning for a networked course. British Journal of Educational Technology November, 33 (5):603-618.

Martensson, M. 2000. A critical review of knowledge management as a tool. Journal of Knowledge Management 4 (3):204-216. 
McVarish, J. and S. Solloway. 2002. Self-evaluation: Creating a classroom without unhealthy competitiveness. Educational Forum Spring, 66 (3):253-260.

O'Connell, J. 1999. From information to knowledge management. What's in it for schools? The Practising Administrator 21 (4):33-37.

Osterman, K. F. 1990. Reflective practice: A new agenda for education. Education and Urban Society February, 22 (2):133-152.

- 1991. Reflective practice: Linking development and school reform. Planning and Changing 22 (3/4):208-217.

Patterson, C., D. Crooks and O. Lukyk-Child. 2002. A new perspective on competencies for self-directed learning. Journal of Nursing Education January, 41 (1):25-31.

Peckham, G. and L. Sutherland. 2000. The role of self-assessment in moderating students' expectations. South African Journal of Higher Education 14 (1):75-78.

Pereira, M. A. 1999. My reflective practice research. Teaching in Higher Education July, 4 (3):339-354.

Pienaar, G. E. 2001. Teaching critical thinking skills in the language classroom. Journal for Language Teaching June, 35 (2):125-137.

Price, B. 2000. Problem-based learning the distance way: A bridge too far? Nurse Education Today February, 20 (2):98-105.

Purdy, M. 1997. The problem of self-assessment in Nurse Education. Nurse Education Today April, 17 (2):135-139.

Riley, B. 1998. You are entering the age of the mind: Thoughts on the knowledge society. Australian Library Journal May, 47 (2):145-156.

Sahin, T. Y. 2003. Student teachers' perceptions of instructional technology: Developing material based on a constructivist approach. British Journal of Educational Technology January, 34 (1):67-74.

Shariq, S. Z. 1998. Sense making and artifacts: An exploration into the role of tools in knowledge management. Journal of Knowledge Management December, 2 (2):10-19.

Schön, D. A. 1983. The reflective practitioner: How professionals think in action. London: Temple Smith.

- 1995. Knowing-in-action: The new scholarship requires a new epistemology. Change November/December:27-34.

Sewell, A. 2002. Constructivism and student misconceptions: Why every teacher needs to know about them. Australian Science Teachers' Journal December, 48 (4):24-28.

Stacey, E. and M. Rice. 2002. Evaluating an online learning environment. Australian Journal of Educational Technology Spring, 18 (3):323-340.

Stallings, V. and C. Vacione. 1996. Student self-assessment and self-evaluation. Mathematics Teacher October, 89 (7):548-554.

Starness, B. A. and C. Paris. 2000. Choosing to learn. Phi Delta Kappa January, 81 (5):392397.

Todd, R. J. 1999. Knowledge management: Utilising the knowledge capital of a learning community. Access 13 (3):11-14.

Tutorial letter 101/ 2003. MEDEM2-R. University of South Africa.

Van Kraayenoord, C. E. and S. G. Paris. 1997. Australian students' self-appraisal of their work samples and academic progress. The Elementary School Journal May, 97 (5):523-537.

Weasmer, J. and A. M. Woods. 2000. Shifting classroom ownership to students. Middle School Journal November, 32 (2):15-20.

Weller, L. D. and G. McElwee. 1997. Strategic management of quality: An American and British perspective. Journal of Research and Development Summer, 30 (4):201-213. 
Wessels, J. 2001. Assessing learning material for distance education: A case study. Politeia 20 (3):34-60.

West-Burnham, J. 1992. Managing quality in schools. London: Longman.

White, C. J. 1999. The metacognitive knowledge of distance learners. Open Learning November, 14 (3):37-46.

Wisniewski, M. A. 2003. Leadership education: A constructivist model for continuing higher education. Journal of Continuing Higher Education Winter, 51 (1):31-37.

Yost, D. S., S. M. Sentner and A. Forlenza- Bailey. 2000. An examination of the construct of critical reflection: Implications for teacher education programming in the 21 st century. Journal of Teacher Education January, February, 51 (1):39-49. 